\title{
IS PROFITABILITY DRIVEN BY WORKING CAPITAL MANAGEMENT? EVIDENCE FOR HIGH-GROWTH FIRMS FROM EMERGING EUROPE
}

\author{
Claudiu BOȚOC ${ }^{1}$, Sorin Gabriel ANTON ${ }^{2}$
}

${ }^{1}$ Department of Finance, Faculty of Economics and Business Administration, West University of Timişoara, Johann Heinrich Pestalozzi Street, No. 16, 300115 Timisoara, Romania Monetary Research Center, University of National and World Economy, Sofia, Bulgaria

${ }^{2}$ Finance, Money, and Public Administration Department, Faculty of Economics and Business Administration, Alexandru Ioan Cuza University of Iasi, Carol I Avenue, No. 11, 700505 Iasi, Romania

E-mails: ${ }^{1}$ claudiu.botoc@e-uvt.ro; ${ }^{2}$ sorin.anton@uaic.ro (corresponding author)

Received 05 May 2017; accepted 05 November 2017

\begin{abstract}
Despite the importance of high-growth firms (HGFs) for job creation, innovation, and economic development in transition economies, current knowledge on the role of financial decisions in explaining their profitability is limited. The aim of this paper is to examine the relationship between working capital management and firm profitability. Using a panel data set on HGFs from Central, Eastern, and South-Eastern Europe during the time span 2006-2015, we found an inverted U-shape relationship between working capital level and firm profitability. Our findings indicate that HGFs should find and maintain the optimal working capital level that maximizes their profitability. Our results proved to be robust when we employ different methodology (quantile regression), different sub-samples as well as alternative measures of profitability and working capital management. The study highlights the importance of short-term financial decisions in enhancing HGFs' profitability, with significant implications for academics and practitioners. We contribute to the extant literature by providing empirical evidence on the existence a concave relationship between working capital level and firm profitability for a cross-country sample of firms.
\end{abstract}

Keywords: working capital management, profitability, high-growth firms, emerging economies, short-term financing policy, Generalized Method of Moments.

JEL Classification: G31, G32, L25.

\section{Introduction}

Academics and policy makers have increasingly recognized the major contribution of high-growth firms (HGFs) to job creation, innovation, and economic growth (Acs, Mueller 2008; Henrekson, Johansson 2010; Lopez-Garcia, Puente 2012; Mason, Brown 2013; Coad et al. 2014). Gazelles, as a subset of HGFs, create more than $50 \%$ of all net new jobs in the developed economies (Anyadike-Danes et al. 2009). Stam and van Stel (2011) argued that HGFs' activity is especially meaningful for economic growth and structural changes in transition countries. Despite their importance and research 
conducted in the last ten years, current knowledge on the determinants of HGFs' performance is limited (Nightingale, Coad 2014; Krasniqi, Desai 2016). To the best of authors' knowledge, there is no study on the role of financial decisions in explaining HGFs' performance, particularly the amount that does not appear in the performance calculation. Greater insight into the determinants of HGFs' performance is of interest to policymakers, scholars and business owners at least twofold. On the one hand, an acceleration of business activity tends to increase the amount of working capital, i.e. generate additional financial constraints for future investments. If these new investments are financed through debt, this leads to an increasing debt ratio and therefore an increase in financial risk. On the other hand, during a recession or in an inflationary period working capital has a paradoxical tendency to grow.

Working capital management (WCM) is important for HGFs facing difficult access to finance and "increased economic uncertainty". This task is prior in continental Europe countries where intercompany financing plays a prominent role in the economy, in contrast to Anglo-Saxon countries where companies have been used to paying promptly. Firm growth can be attained not only through efficient operations but also by using optimal working capital management (Mun, Jang 2015). Buchman et al. (2008) highlighted that the importance of net operating working capital (NWC) as a source of cash to finance growth is often neglected by firms. Padachi (2006) argued that working capital management is "crucial for the survival and growth of small firms". García-Teruel and Martínez-Solano (2007) and Ebben and Johnson (2011) stressed the importance of efficient working capital management for SMEs since they face significant constraints in raising outside debt and equity capital. Aktas et al. (2015) found that corporate investment is the channel through which efficient working capital management contributes to higher firm performance. Furthermore, the authors stressed that efficient working capital management would provide "a new source of internally-generated funds, which could be ultimately employed in more profitable investment opportunities for the benefit of firms' shareholders". Minimizing the amounts of funds tied up in working capital, firms can increase its funds available for investments and expansion.

In the last decades, the role of working capital management has been reconsidered in the extant literature. Thus, if the traditional view considered working capital only "a positive component of the balance sheet", later, the modern view considered working capital a "drag on financial performance" (Sagner 2011). Managers can increase firm profitability by reducing the amount of money invested in working capital or by reducing the cash conversion cycle to a minimum level. Several empirical studies support this former view by finding a linear and negative relationship between working capital and firm profitability (Shin, Soenen 1998; Deloof 2003; García-Teruel, Martínez-Solano 2007; Ebben, Johnson 2011; Aktas et al. 2015). However, recent studies have found a non-linear (inverted U-shape) relationship between working capital and firm performance, suggesting that there is an optimal level of working capital that can maximize the firm's profitability or value (Baños-Caballero et al. 2014; Afrifa, Padachi 2016).

Given these, the aim of the paper is to investigate the impact of WCM on firm profitability for a sample of 937 HGFs located in Central, Eastern, and South-Eastern European 
(CESEE) countries for the 2006-2015 period. Using Generalized Method of Moments (GMM) method, the results do not reject the non-linear (concave) relation between profitability and working capital ratio, with an optimum level of 0.79 from sales. When quantile regression was considered, the results further support the heterogeneity in the relationship between profitability and working capital ratio as well as other controls. That is, the positive effect associated with working capital and the negative effect respectively associated with its square are more pronounced for firms at the lower and higher profitability quantiles than firms at the medium quantiles.

Our study contributes to the extant knowledge in four ways. Firstly, we provide new evidence for the effect of WCM on HGFs' performance by using a ratio for cash frozen in working capital instead of the length of operating cycle predominantly used in previous studies. Secondly, unlike previous studies which have focused only on samples located in one country or one industry, it is the first study that deals with cross-country sample. We analyze HGFs located in CESEE region, where all the countries have a bank-based system, with less developed capital markets. Therefore, given that external financing is mainly debt based, financing through trade credit is a viable alternative. According to the European Payment Report (2016), conditions vary across countries/regions within Europe. For instance, in Eastern Europe the average payment term is 22.46 days, the percentage of yearly revenues that have to be written off range between $0.8 \%$ and $4.2 \%$ and only $33 \%$ of businesses have sufficient access to credit. This different payment behavior in comparison with South Europe (Spain, Portugal) or West-Central Europe (UK, Belgium) represents the motivation for the current work. Thirdly, our analysis relates to a longer and recent period of time, comprising both economic growth and downturn when working capital policy experienced different behavior. Fourthly, we extend previous studies in terms of the methodology employed for testing the non-linear relation. That is, we use panel data as a benchmark and a more suitable approach through quantile regression. The latter approach deals with heterogeneous companies and limitations of mean coefficients, by providing an entire distribution of coefficient estimate sets.

The remainder of this paper is organized as follows. Section 1 provides a concise literature review on the effect of WCM on firm performance. Section 2 presents data and methodology employed in the paper. The empirical results are presented in Section 3. Finally, in the last section, conclusions are presented.

\section{Literature review}

As most of the extant studies focused on long-term financial decisions (financing and investment decisions), there are insufficient papers on the effects of short-term financial decisions (Faden 2014). Several papers focused on the impact of WCM on firm performance, but their results are still mixed and ambiguous.

Most of the previous papers focused on large (public) firms from developed economies - Belgium (Deloof 2003), USA (Shin, Soenen 1998; Aktas et al. 2015), United Kingdom (Baños-Caballero et al. 2014), Greece (Lazaridis, Tryfonidis 2006), Finland (Enqvist et al. 2014) - or on firms from one sector - restaurant firms (Mun, Jang 2015). 
Recently, a growing number of articles analyzed the impact of liquidity/WCM on firm profitability (Dănuleţiu 2010; Bolek 2013; Boţoc 2013; Barjaktarović Rakočević et al. 2014; Cristea, C., Cristea, M. 2016; Svitlík, Poutník 2016) and on capital structure (Denčić-Mihajlov et al. 2015) using samples of listed firms from CESEE countries. Despite the importance of WCM for small and medium - sized enterprises (SMEs), only a few papers analyzed its effects on the SMEs' profitability using samples for developed economies (García-Teruel, Martínez-Solano 2007; Ebben, Johnson 2011; Baños-Caballero et al. 2012; Pais, Gama 2015; Afrifa, Padachi 2016) or for developing economies (Padachi 2006).

Several past studies documented a negative relationship between working capital management and firm profitability (Shin, Soenen 1998; Deloof 2003; García-Teruel, Martínez-Solano 2007; Ebben, Johnson 2011; Aregbeyen 2013; Aktas et al. 2015). In his seminal paper, Deloof (2003) analyzed a sample of large Belgian non-financial firms covering the period 1992-1996 and found a negative linear relationship between cash conversion cycle (CCC) and operating performance, measured by gross operating income. Also, the author found a negative and statistically significant relationship between the components of CCC (the number of days accounts receivable, inventories, and accounts payable) and firm profitability. These results suggest that managers can improve firm profitability (or increase its value) by reducing its inventories and the number of days accounts receivable to some acceptable minimum level. Enqvist et al. (2014) find a strong negative relation between the cash conversion cycle and firm profitability for a large sample of Finish listed firms for the 1990-2008 period. The authors also documented that the impact of efficient working capital management on firm profitability is higher in economic downturns.

García-Teruel and Martínez-Solano (2007) found also a negative relationship between cash conversion cycle and firm profitability on a sample of 8,872 SMEs from Spain for the period from 1996 to 2002. Their results suggest that shortening the CCC can increase firm profitability. However, there are some divergences related to the relationship between various components of working capital and firm profitability. In contrast to results reported by Deloof (2003), Garcia-Teruel and Martinez-Solano (2007) found that the relationship between accounts payable and firm performance is not significant when they control for endogeneity issues.

The negative relationship between liquidity/WCM and profitability is partially confirmed for listed firms from CESEE region. Employing a small sample of seventeen firms listed on the Bucharest Stock Exchange during the period 2011-2015, Cristea, C. and Cristea, M. (2016) found a negative relationship between cash conversion cycle and profitability. Also, the results of panel data analysis suggest a negative and statistically significant relationship between the three components of CCC and ROA. The authors reported that Romanian listed firms exhibit higher values for CCC (114.69 days) than firms located in developed economies. Boţoc (2013) employed a larger sample of Romanian listed firms over the period 2001-2011 and found a negative relationship between working capital and profitability measured by return on sales. According to these results, Romanian public firms can increase profitability by reducing the cash conversion 
cycle. A weak negative linear correlation between WCM and firm profitability was documented by Danuleţiu (2010) for a sample of firms from Alba country (Romania) over the period 2004-2008.

Barjaktarović Rakočević et al. (2014) examined the profitability-liquidity relationship within Serbian firms listed on the Belgrade Stock Exchange using correlation analysis. They found a negative correlation between profitability (measured by ROA) and the number of days accounts receivable and the number of days accounts payable. Also, the study showed no statistically significant relationship between CCC and the profitability indicator. Bolek (2013) studied a sample of Polish firms listed on Warsaw Stock Exchange over the period 1997-2007 and found no relationship between working capital indicators and profitability ratios. Svitlík and Poutník (2016) analyzed the relationship among working capital, liquidity ratios and profitability ratios in the Czech Republic during the period 2003-2013 using correlation analysis. They found statistically significant correlation between profitability (measured by ROA) and working capital turnover for most of the years, most of the economic sectors, both consolidated and unconsolidated data and very large firms.

The main limits of these aforementioned studies focused on emerging Europe are the following: (1) they focused only on samples of listed firms from one country; (2) from methodological point of view, they employ only correlation analysis and static panel data methodologies and did not control for endogeneity issues; (3) they used extensively $\mathrm{CCC}$ and its components as proxies for working capital management, but these variables do not reflect the amount of money involved within the operating cycle.

Recently, Mun and Jang (2015) and Afrifa and Padachi (2016) found a concave (or inverted U-shape) relationship between working capital level and firm profitability. These results indicate the existence of an optimal working capital level at which firms' profitability is maximized. However, their results are limited to the sample of firms employed - all Alternative Investment Market (AIM) listed SMEs (Afrifa, Padachi 2016) or restaurant firms from USA (Mun, Jang 2015) - and cannot be generalized to a cross-country sample. Furthermore, Baños-Caballero et al. (2014) found an inverted U-shaped relationship between a firm's net trading cycle, which is similar to CCC, and its performance measured by Tobin'Q. Their sample includes nonfinancial quoted firms from the United Kingdom for the period 2001-2007. According to their findings, managers should find and maintain an optimal level of accounts receivable, accounts payable, and inventories that can maximize the firm's value.

In explaining the impact of WCM on firm profitability, previous papers have employed as control variables mainly firm size, opportunity growth, leverage, and quick ratio. Most of the previous papers found a negative relationship between leverage and firm profitability. Firm size, opportunity growth (measured by growth of sales), and quick ratio have been found to influence positively firm profitability (Deloof 2003; BañosCaballero et al. 2012; Enqvist et al. 2014; among others).

As highlighted by Hill et al. (2010), HGFs employ more aggressive working capital strategies. As a consequence, investments in working capital (in the first phase) can 
increase sales, margin, and profitability. After the optimal level is reached, overinvestments in working capital can generate losses. Following the recent literature, we propose to test the following hypothesis:

H1: There is a non-linear relationship between the working capital ratio and profitability with an optimal level that maximizes firm performance.

\section{Data and methodology}

We consider the Eurostat-OECD's definition proposed in the Manual on Business Demography Statistics (Eurostat-OECD 2007) and used by both international institutions in reporting statistics on HGFs/fast-growing firms. According to this definition, gazelles $^{1}$, as a subset of HGFs, are firm up to five years old, with at least 10 employees in the starting year (2006 in our case), and an average annualized growth exceeding $20 \%$ over a three-year period (2007-2009). Firm growth could be measured by the number of employees and by turnover. Given that Daunfeldt et al. (2014) highlighted that the results are not sensitive to which one is chosen, we used employment growth as selection criteria. Despite its drawbacks (Daunfeldt et al. 2015), Eurostat-OECD's definition has been used extensively in the extant literature in the last years (Coad et al. 2014; Hölzl 2014; Mohr et al. 2014; Giner et al. 2017) and we consider that it is appropriate for our sample of firms as it reduces the small size class bias and it allows comparisons across countries and over time. Furthermore, this definition is time-independent, in contrast to most definitions that define HGFs as the $1 \%$ or $5 \%$ of firms with highest growth rates.

We collect firm-level data from Orbis Database (June 2016 Edition), a well-known and widely used commercial database provided by Bureau van Dijk, where several criteria have been considered. First, we focus our study on gazelles located in 20 CESEE countries $^{2}$, for the period 2006-2015, which lead to an original sample of 1,163 gazelles. Second, we exclude financial firms given different particularities for this sector (42 firms). Third, we require non-missing data for the working capital ratio (177 firms with missing working capital data). Fourth, we eliminate firms within countries with less than 50 firm-observations ( 7 firms). This leaves us with the final sample of 937 gazelles firms from 13 countries and 5,808 firm-year observations. Furthermore, all firm financial variables were winsorized at the 1st and 99th percentiles in order to overcome the influence of outliers. Country level data that deal with financial development process are gathered from Global Financial Development Database (World Bank).

We measure profitability, i.e. the dependent variable, through Return on Assets (ROA), defined as net income to total assets ratio. Given that usually working capital is related to EBIT performance, for the robustness purpose it has been considered Return on Invested Capital (ROIC) defined as EBIT to total assets ratio.

\footnotetext{
${ }^{1}$ The term gazelle has been introduced by Birch et al. (1993).

2 Albania, Belarus, Bosnia and Herzegovina, Bulgaria, Croatia, Czech Republic, Estonia, Hungary, Kosovo, Latvia, Lithuania, Macedonia, Moldova, Montenegro, Poland, Romania, Serbia, Slovak Republic, Slovenia, and Ukraine.
} 
It's worth to be mentioned that for the variable of interest, most of the previous studies employed either cash conversion cycle (Deloof 2003; Ebben, Johnson 2011) or net trade cycle (Shin, Soenen 1998; Baños-Caballero et al. 2012, 2014) as proxy for working capital management. Given the relatively low magnitude of such variable that reflects a length of time, we preferred in our model a proxy that reflects rather the amount of money involved within the operating cycle, i.e. working capital ratio (WKCR). WKCR is defined as (Stocks+Debtors-Creditors)/Sales and one expects a non-linear relation with firm profitability. The curve estimation regression statistics suggests that the quadratic function is suitable for the model, with the highest R-squared of 0.041 . Furthermore, the scatter plot suggests that the association between ROA and WKCR is not linear, and record a quadratic inverted U-shape (see Fig. 1). This motivates the inclusion of WCKR square in the model $\left(\mathrm{WKCR}^{2}\right)$.

As the chart illustrates, low level of profitability could be associated with both low and high level of WKCR. The coefficients for the variables allow us to determine for our sample of HGFs the turning point in the relationship between the profitability of firms and working capital. Particularly, we find a turning point of 0.797 for WKCR associated with the highest ROA (0.076).

In order to capture other influences on the profitability, additional firm control and country control variables have been considered, following the previous papers. Firstly, debt ratio (DR) is considered since we are dealing with the financing impact over profitability. DR is defined as (Non-current liabilities + Loans) / Total Assets. Secondly, for measuring growth opportunities we use the one-year growth rate in sales (SGR). Thirdly, we proxy for the cash that appears in the balance sheet by using Cash and Cash equivalents to Total Assets Ratio (CR).

Given that the sample includes several CESEE countries that might be characterized by different business environments, two country-variables have been considered. Although it is difficult to measure financial development in practice, we follow the framework developed by World Bank and include two proxy variables related to financial depth

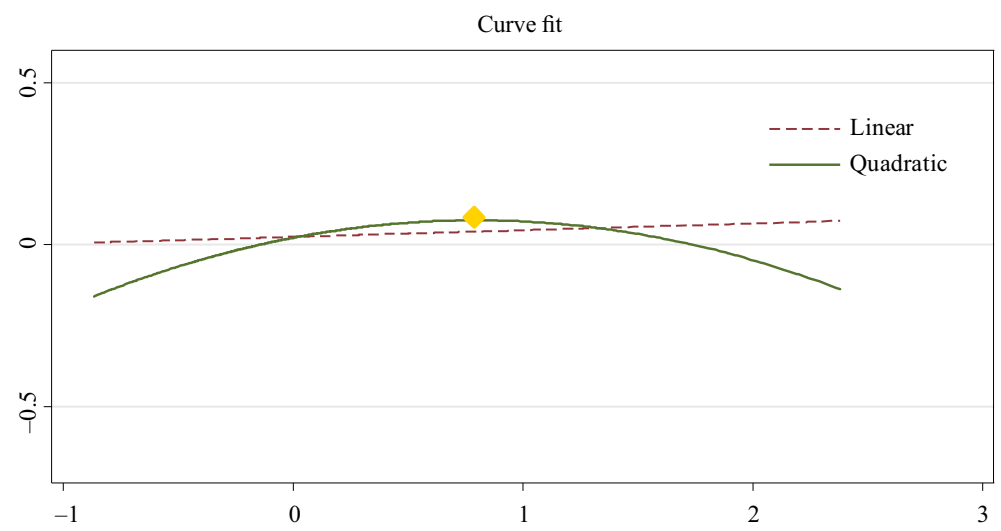

Fig. 1. Curve estimation regression models between ROA and WKCR 
and to efficiency. On the one hand, financial system deposits to GDP (DI08) is defined as demand, time and saving deposits in deposit money banks and other financial institutions as a share of GDP. Financial sector development could support the growth of firms by providing them with access to finance, and therefore a positive relation is hypothesized. On the other hand, Boone indicator (OI05) reflect a measure of the degree of competition based on profit-efficiency in the banking market which is calculated as the elasticity of profits to marginal costs. An increase in the Boone indicator implies a deterioration of the competitive conduct of financial intermediaries, and therefore a negative relation is hypothesized.

Finally, since our study spans ten years between 2006 and 2015, we include a dummy variable in order to see if the relationship between working capital and profitability may have been affected by the financial crisis. According to the common view that the global financial crisis spans the period of $2007 / 8-2008 / 9^{3}$, our dummy variable (DCRISIS) takes value 1 for the years 2007 and 2008 and 0 for the others.

In terms of methodology, we attempt to extend the previous studies by using two approaches. First, we tested our relation with appropriate panel data models, given the benefits of this methodology. It is well known that panel data has the main advantage that it accounts for individual heterogeneity, i.e. it allows controlling for variables one cannot observe or measure across companies. In this respect, we have started with an OLS model as a benchmark and after that, we have added fixed/random effects models in order to deal with firm and time effect, as well as dynamic panel model with twostep GMM estimator proposed by Arellano and Bond (1991) given the endogeneity and dynamic issues. For GMM-system it is necessary to determine what variables are endogenous and how many lags to include as internal instruments ${ }^{4}$. In order to see if two lags are sufficient to ensure dynamic completeness, we estimate a regression of current profitability on four lags of past profitability, controlling for other firm variables. As a consequence, for both endogenous and dependent variables, we consider only lagged t-3 to t-5 instruments. By employing specific tests ${ }^{5}$ WKCR and SGR are treated as endogenous and all remaining variables (i.e. DR, CR, DI08, OI05, and DCRISIS) are treated as exogenous.

Given these, the following empirical model has been tested:

$$
\begin{aligned}
& R O A_{i t}=\alpha+\beta_{1} \times R O A_{i t-1}+\beta_{2} \times R O A_{i t-2}+\beta_{3} \times W K C R_{i t}+\beta_{4} \times W K C R_{i t}^{2}+ \\
& \gamma \times X_{i t}^{\prime}+\delta_{1} \times D I 08_{i t}+\delta_{2} \times O I 05_{i t}+\delta_{3} \times D C R I S I S+\mu_{i t}+\lambda_{j}+\vartheta_{i t},
\end{aligned}
$$

\footnotetext{
${ }^{3}$ The USA's subprime crisis in August 2007 has been indicated as the beginning of the global financial crisis in several articles, whilst others consider the Lehman Brothers' collapse in September 2008 as either the beginning of the crisis or the second phase of the crisis.

${ }^{4}$ For GMM-system options we include the orthogonal option since the panel exhibit gaps; collapse option, to avoid instrument proliferation; two-step estimation with robust option to trigger Windmeijer correction of standard errors (Windmeijer 2005).

${ }^{5}$ Our first set of tests involve OLS regressions of (1) current levels of working capital, and other firm-variables and (2) changes in these levels on past profitability and historical values of the firmvariables. We carry out a second test of strict exogeneity suggested by Wooldridge (2002: 285).
} 
where $\mu_{i t}$ denotes the unobservable firm and time effects, $\lambda_{j}$ is an industry unobservable effect and $\vartheta_{i t}$ is the idiosyncratic error component.

Second, as a robustness check, we explore in depth the nonlinearity relation with quantile regression, given the high variation in ROA. The main advantage of the quantile regression relates to a richer characterization and description of the data, i.e. it can show different effects of the WKCR on the ROA depending across the spectrum of the ROA. The quantile regression model was developed by Koenker and Bassett (1978) as follow:

$$
y_{i t}=x_{i t}^{\prime} \beta_{0}+\varepsilon_{i t}
$$

with

$$
\operatorname{Quant}_{\theta}\left(y_{i t} \mid x_{i t}\right)=x_{i t}^{\prime} \beta_{0},
$$

where $y_{i t}$ represent the dependent variable, $x_{i t}$ represent a vector of regressors, $\beta$ is the vector of parameters to be estimated, $\varepsilon$ is a vector of residuals, $i$ denotes firm and $t$ denotes time. Quant $\theta\left(y_{i t} \mid x_{i t}\right)$ denotes the $\theta^{\text {th }}$ conditional quantile of $y_{i t}$ given $x_{i t}$.

Table 1. Descriptive statistics

\begin{tabular}{lccccccc}
\hline \multirow{2}{*}{ Country } & \multirow{2}{*}{ Obs. } & \multicolumn{3}{c}{ ROA } & \multicolumn{3}{c}{ WKCR } \\
\cline { 3 - 8 } & & Mean & Median & St. dev. & Mean & Median & St. dev. \\
\hline Bosnia and Herzegovina & 60 & 0.061 & 0.017 & 0.139 & 0.395 & 0.063 & 2.113 \\
\hline Bulgaria & 709 & 0.058 & 0.048 & 0.163 & 0.232 & 0.108 & 0.586 \\
\hline Czech Republic & 787 & 0.050 & 0.037 & 0.152 & 0.096 & 0.087 & 0.359 \\
\hline Estonia & 67 & 0.087 & 0.082 & 0.201 & 0.144 & 0.101 & 0.160 \\
\hline Croatia & 145 & 0.023 & 0.016 & 0.152 & 0.190 & 0.197 & 0.410 \\
\hline Hungary & 58 & 0.003 & 0.017 & 0.128 & 0.194 & 0.164 & 0.206 \\
\hline Lithuania & 73 & 0.071 & 0.055 & 0.100 & 0.059 & 0.054 & 0.081 \\
\hline Latvia & 179 & 0.030 & 0.027 & 0.226 & 0.074 & 0.065 & 0.418 \\
\hline Poland & 182 & 0.051 & 0.046 & 0.132 & 0.111 & 0.098 & 0.199 \\
\hline Romania & 581 & 0.029 & 0.020 & 0.182 & 0.228 & 0.203 & 2.951 \\
\hline Serbia & 494 & 0.062 & 0.040 & 0.183 & 0.155 & 0.108 & 0.393 \\
\hline Slovakia & 362 & 0.051 & 0.045 & 0.174 & 0.080 & 0.077 & 0.324 \\
\hline Ukraine & 2111 & -0.009 & 0.006 & 0.206 & 0.595 & 0.045 & 77.114 \\
\hline Total & $\mathbf{5 8 0 8}$ & $\mathbf{0 . 0 2 8}$ & $\mathbf{0 . 0 2 4}$ & $\mathbf{0 . 1 8 5}$ & $\mathbf{0 . 1 5 8}$ & $\mathbf{0 . 0 8 9}$ & $\mathbf{0 . 3 9 7}$ \\
\hline
\end{tabular}

Notes: ROA stands for Return on Assets; WKCR the working capital ratio.

Table 1 reports main descriptive statistics for the variables of interest considered in the empirical model for each country. The average working capital ratio is $15.8 \%$ of sales percent whereas the lowest ratio is recorded in Lithuania (5.9\%), and the highest ratio is recorded in Ukraine (59.5\%). Consistent with non-linear behavior, the extreme values of WKCR are not associated with the extreme values of ROA. 
One can assert that for a relatively high growth rate $(52 \%)$, i.e. the main criteria for sample construction, companies record a low profitability (average ROA 2.8\%) and require an important level of the working capital ratio (average WKCR $15.8 \%$ of sales). On average, debt finances $23.8 \%$ of total assets, while $8.4 \%$ of cash is left as security margin. Regarding the financial development of the countries included, the financial depth is medium with $43 \%$ financial system deposits as a share of GDP and relatively high degree of competition (average Boone indicator-0.11). Correlation matrix reported in Table 2 highlights low correlations between independent variables, suggesting no multicollinearity issue.

Table 2. Correlation matrix

\begin{tabular}{lcccccccc}
\hline Variables & ROA & WKCR & DR & SGR & CR & DI08 & OI05 & DCRISIS \\
\hline ROA & 1.000 & & & & & & & \\
\hline WKCR & 0.071 & 1.000 & & & & & & \\
\hline DR & -0.244 & 0.158 & 1.000 & & & & & \\
\hline SGR & 0.012 & -0.029 & 0.046 & 1.000 & & & & \\
\hline CR & 0.197 & -0.104 & -0.199 & 0.007 & 1.000 & & & \\
\hline DI08 & 0.066 & 0.040 & -0.047 & -0.148 & 0.163 & 1.000 & & \\
\hline OI05 & -0.021 & 0.025 & -0.023 & -0.018 & 0.071 & 0.256 & 1.000 & \\
\hline DCRISIS & 0.066 & -0.060 & 0.017 & 0.308 & 0.050 & -0.212 & -0.087 & 1.000 \\
\hline
\end{tabular}

Notes: ROA stands for Return on Assets; WKCR the working capital ratio; DR the debt ratio; SGR the sales growth ratio; CR - Cash and Cash equivalents to Total Assets Ratio; DI08 - Financial system deposits to GDP (\%); OI05 - Boone Indicator - measure of degree of competition calculated as the elasticity of profits to marginal costs; DCRISIS - dummy for year crisis.

\section{Results}

\subsection{Effects of working capital on HGF's profitability}

The results obtained from Eq. (1) are provided in Table 3, columns 1 to 4 reporting the results for the Ordinary Least Square Model (OLS), the Fixed Effects Model (FE), the Random Effects Models (RE), and GMM-System Model (GMM-SYS) respectively. A variance inflation factors test has been carried out in order to detect potential multicollinearity, the results suggesting no multicollinearity among our variables, given that mean VIF (1.48) is below the threshold (the rule of thumb from the literature: VIF lower than four).

The coefficient for the WKCR variable $\left(\beta_{1}\right)$ is positive and for its square $\left(\beta_{2}\right)$ is negative. Thus, the results do not reject the research hypothesis, suggesting the existence of a concave relation between firm profitability and working capital ratio, for all models considered. Below the optimal level of 0.79 of sales, working capital has a positive impact, most likely due to credit sales policy. Higher operating working capital through longer sales terms, a higher value of inventories, or short-term payables may increase sales and thus improve operational performance. Above the optimal level, working capi- 
Table 3. Profitability and working capital

\begin{tabular}{|c|c|c|c|c|}
\hline Models & (1) & (2) & (3) & (4) \\
\hline Variables & OLS & FE & $\mathrm{RE}$ & GMM-SYS \\
\hline \multirow[t]{2}{*}{ L.ROA } & $0.389^{* * *}$ & $0.048^{* * *}$ & $0.315^{* * *}$ & $0.738^{* *}$ \\
\hline & $(0.017)$ & $(0.018)$ & $(0.017)$ & $(0.307)$ \\
\hline \multirow[t]{2}{*}{ L2.ROA } & $0.087^{* * *}$ & $-0.117^{* * *}$ & $0.051^{* * *}$ & -0.177 \\
\hline & $(0.016)$ & $(0.017)$ & $(0.016)$ & $(0.149)$ \\
\hline \multirow[t]{2}{*}{ WKCR } & $0.088^{* * *}$ & $0.116^{* * *}$ & $0.101^{* * *}$ & $0.327^{* * *}$ \\
\hline & $(0.011)$ & $(0.016)$ & $(0.011)$ & $(0.147)$ \\
\hline \multirow[t]{2}{*}{$\mathrm{WKCR}^{2}$} & $-0.044^{* * *}$ & $-0.053^{* * *}$ & $-0.048^{* * *}$ & $-0.099^{*}$ \\
\hline & $(0.006)$ & $(0.008)$ & $(0.007)$ & $(0.058)$ \\
\hline \multirow[t]{2}{*}{ DR } & $-0.103^{* * *}$ & $-0.231^{* * *}$ & $-0.124^{* * *}$ & $-0.145^{* * *}$ \\
\hline & $(0.009)$ & $(0.016)$ & $(0.010)$ & $(0.042)$ \\
\hline \multirow[t]{2}{*}{ SGR } & $0.018^{* * *}$ & $0.010^{* * *}$ & $0.016^{* * *}$ & $0.059^{* *}$ \\
\hline & $(0.002)$ & $(0.002)$ & $(0.002)$ & $(0.029)$ \\
\hline \multirow[t]{2}{*}{$\mathrm{CR}$} & $0.111^{* * *}$ & $0.222^{* * *}$ & $0.142^{* * *}$ & $0.138^{* *}$ \\
\hline & $(0.022)$ & $(0.034)$ & $(0.024)$ & $(0.055)$ \\
\hline \multirow[t]{2}{*}{ DI08 } & $0.077^{* * *}$ & $-0.417^{* * *}$ & $0.065^{* * *}$ & -0.062 \\
\hline & $(0.021)$ & $(0.073)$ & $(0.025)$ & $(0.138)$ \\
\hline \multirow[t]{2}{*}{ OI05 } & $-0.030^{* * *}$ & $-0.027^{* *}$ & $-0.032^{* * *}$ & $-0.025^{* *}$ \\
\hline & $(0.010)$ & $(0.011)$ & $(0.010)$ & $(0.014)$ \\
\hline \multirow[t]{2}{*}{ DCRISIS } & 0.002 & 0.011 & 0.008 & -0.021 \\
\hline & $(0.008)$ & $(0.008)$ & $(0.007)$ & $(0.020)$ \\
\hline \multirow[t]{2}{*}{ CONS } & $-0.029^{* * *}$ & $0.240^{* * *}$ & -0.020 & 0.027 \\
\hline & $(0.011)$ & $(0.035)$ & $(0.012)$ & $(0.081)$ \\
\hline R-Squared & 0.307 & 0.118 & 0.301 & \\
\hline Mean VIF & 1.48 & & & \\
\hline \# Instruments & & & & 38 \\
\hline Country effect & & & & YES \\
\hline Hausman test (p-value) & \multicolumn{4}{|c|}{$\mathrm{Chi}^{2}(8)=992.96^{* * *}$} \\
\hline Modified Wald ${ }^{a}$ ( -value) & \multicolumn{4}{|c|}{$\mathrm{Chi}^{2}(704)=6.1 \mathrm{e}+13^{* * *}$} \\
\hline Wooldridge $^{\mathrm{b}}$ (p-value) & \multicolumn{4}{|c|}{$\mathrm{F}(1,681)=53.39^{* * *}$} \\
\hline $\mathrm{AR}^{\mathrm{c}}$ (p-value) & & & & 0.255 \\
\hline Sargan test ${ }^{\mathrm{d}}$ (p-value) & & & & 0.379 \\
\hline Hansen test ${ }^{\mathrm{d}}$ (p-value) & & & & 0.765 \\
\hline
\end{tabular}

Notes: Standard errors in parentheses; $* p<0.1, * * p<0.05, * * * p<0.01$; ${ }^{*}$ Modified Wald test for heteroskedasticity; ${ }^{b}$ Wooldridge test for autocorrelation; ${ }^{c} \mathrm{AR}(2)$ is a test for second-order serial correlation in the first-differenced residuals, under the null of no serial correlation; ${ }^{\mathrm{d}}$ The Sargan/Hansen tests of over-identification is under the null that all instruments are valid.

Source: author's calculation. 
tal has a negative impact, most likely due to the cost of trade credit. Our results suggest that investments in the working capital do not cover the cost of capital and thus decrease profitability. Although the sign of WKCR variable and its square remain unchanged for all models, the higher magnitude is recorded for GMM-System estimator, given the increased efficiency in two-step estimation. Furthermore, the non-visible cash through WKCR has a higher impact on profitability than visible cash through CR.

Regarding controls, all variables, barring DI08 and DCRISIS are significant and consistent with the expected sign. The debt ratio is negatively associated with profitability, which does not reject Pecking Order Theory of capital structure. This result is in line with those reported by Deloof (2003), Lazaridis and Tryfonidis (2006), Aregbeyen (2013), and Enqvist et al. (2014) in similar studies. Both sales growth rate and cash ratio are positively associated with profitability, the latter having a double impact, reinforcing the "cash is king" principle during the crisis period. HGFs with higher growth opportunities and more cash exhibit higher profitability.

The consistency of the GMM-System is supported by additional tests for serial correlation in second difference ( $p$-value $>0.1$ ) and the validity of instruments ( $p$-value $>0.1$ ). The main difference between GMM System and the other models relates to the insignificance of financial depth (DI08) on profitability, for which the effect could be absorbed by firm growth variable. One can argue that is more important the efficiency rather than the financial depth of the financial systems. The financial crisis is not significant in affecting the profitability, which could be explained by the fact that the firms analyzed have experienced an average annualized growth exceeding $20 \%$ over the period 2007-2009.

\subsection{Robustness checks}

In order to provide robustness for our results, three approaches have been considered. First, it is likely to exhibit differences among countries in terms of quality of business and legal environment, (i.e. financial market development, availability of short-term loans, etc.). Due to the fact that Ukraine contributes the most $(2,111$ firm-year observations or $36.34 \%$ of the entire sample) we split the sample into companies from Ukraine (UA) and those from other countries (NON-UA), the results being reported in Table 4, columns 2 and 3.

Second, we use alternative measures for dependent variable - Return on Invested Capital - as well as for variable of interest - Cash Conversion Cycle. CCC is a proxy for working capital computed as the number of days accounts receivable + the number of days inventory - the number of days accounts payable. Thus, considering the GMMSystem estimation and the entire sample as a benchmark, the results are reported in Table 4, columns 4, 5 and 6.

For the subsamples, one can observe that the relationship between working capital and profitability is non-linear for both Ukraine and all other countries. For the NON-UA the impact of control variables is similar to the benchmark, whereas, in Ukraine, cash ratio and efficiency of the financial system are not significant in explaining the profitability. 
Table 4. Robustness check results

\begin{tabular}{|c|c|c|c|c|c|c|}
\hline \multirow{2}{*}{ DEP. VAR. } & \multicolumn{3}{|c|}{ Sample } & \multicolumn{3}{|c|}{ Alternative proxies } \\
\hline & (1) & (2) & (3) & (4) & (5) & (6) \\
\hline Variables & ROA & UA & NON-UA & ROA & ROIC & ROIC \\
\hline \multirow[t]{2}{*}{ L.ROA } & $0.738^{* *}$ & $0.258^{*}$ & $0.609^{* *}$ & $0.630^{* *}$ & & \\
\hline & $(0.307)$ & $(0.356)$ & $(0.260)$ & $(0.294)$ & & \\
\hline \multirow[t]{2}{*}{ L2.ROA } & -0.177 & 0.021 & -0.004 & -0.080 & & \\
\hline & $(0.149)$ & $(0.136)$ & $(0.119)$ & $(0.138)$ & & \\
\hline \multirow[t]{2}{*}{ L.ROIC } & & & & & $0.286^{*}$ & $0.465^{*}$ \\
\hline & & & & & $(0.312)$ & $(0.306)$ \\
\hline \multirow[t]{2}{*}{ L2.ROIC } & & & & & 0.057 & 0.015 \\
\hline & & & & & $(0.128)$ & $(0.139)$ \\
\hline \multirow[t]{2}{*}{ WKCR } & $0.327^{* *}$ & $0.276^{*}$ & $0.064^{* *}$ & & $0.230^{* *}$ & \\
\hline & $(0.147)$ & $(0.159)$ & $(0.083)$ & & $(0.097)$ & \\
\hline \multirow[t]{2}{*}{$\mathrm{WKCR}^{2}$} & $-0.099^{*}$ & $-0.077^{*}$ & $-0.047^{*}$ & & $-0.142^{*}$ & \\
\hline & $(0.058)$ & $(0.072)$ & $(0.047)$ & & $(0.074)$ & \\
\hline \multirow[t]{2}{*}{$\mathrm{CCC}$} & & & & $8.27 \mathrm{e}-04^{* *}$ & & $3.8 \mathrm{e}-04^{* *}$ \\
\hline & & & & $(5.42 \mathrm{e}-04)$ & & $(4.41 \mathrm{e}-04)$ \\
\hline \multirow[t]{2}{*}{$\mathrm{CCC}^{2}$} & & & & $-1.57 \mathrm{e}-06^{*}$ & & $-1.03 \mathrm{e}-06^{*}$ \\
\hline & & & & $(2.66 \mathrm{e}-06)$ & & $(2.49 \mathrm{e}-06)$ \\
\hline \multirow[t]{2}{*}{$\mathrm{DR}$} & $-0.145^{* * *}$ & $-0.199^{* * *}$ & $-0.045^{* * *}$ & $-0.130^{* * *}$ & $-0.103^{* * *}$ & $-0.081^{* * *}$ \\
\hline & $(0.042)$ & $(0.059)$ & $(0.032)$ & $(0.038)$ & $(0.028)$ & $(0.030)$ \\
\hline \multirow[t]{2}{*}{ SGR } & $0.059^{* *}$ & $0.026^{*}$ & $0.035^{* *}$ & $0.072^{* *}$ & $0.026^{* *}$ & $0.051^{* *}$ \\
\hline & $(0.029)$ & $(0.016)$ & $(0.085)$ & $(0.036)$ & $(0.033)$ & $(0.041)$ \\
\hline \multirow[t]{2}{*}{$\mathrm{CR}$} & $0.138^{* *}$ & 0.083 & $0.143^{* *}$ & $0.123^{* *}$ & $0.158^{* * *}$ & $0.118^{* *}$ \\
\hline & $(0.055)$ & $(0.106)$ & $(0.059)$ & $(0.050)$ & $(0.060)$ & $(0.063)$ \\
\hline \multirow[t]{2}{*}{ DI08 } & -0.062 & -0.382 & 0.114 & 0.065 & -0.198 & -0.018 \\
\hline & $(0.138)$ & $(0.245)$ & $(0.215)$ & $(0.145)$ & $(0.176)$ & $(0.203)$ \\
\hline \multirow[t]{2}{*}{ OI05 } & $-0.025^{*}$ & -0.019 & $-0.002^{*}$ & $-0.021^{*}$ & $-0.026^{*}$ & $-0.022^{*}$ \\
\hline & $(0.014)$ & $(0.015)$ & $(0.022)$ & $(0.014)$ & $(0.014)$ & $(0.014)$ \\
\hline \multirow[t]{2}{*}{ DCRISIS } & -0.021 & -0.013 & 0.005 & -0.020 & 0.010 & -0.002 \\
\hline & $(0.020)$ & $(0.028)$ & $(0.040)$ & $(0.020)$ & $(0.021)$ & $(0.023)$ \\
\hline \multirow[t]{2}{*}{ CONS } & 0.027 & 0.136 & -0.047 & -0.020 & 0.125 & 0.039 \\
\hline & $(0.081)$ & $(0.096)$ & $(0.108)$ & $(0.076)$ & $(0.098)$ & $(0.100)$ \\
\hline \# Instruments & 38 & 26 & 37 & 38 & 38 & 38 \\
\hline $\mathrm{AR}^{\mathrm{a}}$ (p-value) & 0.255 & 0.627 & 0.384 & 0.255 & 0.952 & 0.952 \\
\hline $\begin{array}{l}\text { Sargan test }{ }^{\mathrm{b}} \\
\text { (p-value) }\end{array}$ & 0.379 & 0.030 & 0.132 & 0.379 & 0.450 & 0.450 \\
\hline $\begin{array}{l}\text { Hansen test }{ }^{\mathrm{b}} \\
\text { (p-value) }\end{array}$ & 0.765 & 0.221 & 0.410 & 0.765 & 0.775 & 0.775 \\
\hline
\end{tabular}

Notes: Standard errors in parentheses; ${ }^{*} p<0.1,{ }^{* *} p<0.05,{ }^{* * *} p<0.01$; ${ }^{\text {a }} \mathrm{AR}(2)$ is test for secondorder serial correlation in the first-differenced residuals, under the null of no serial correlation; ${ }^{\mathrm{b}} \mathrm{The}$ Sargan/Hansen tests of over-identification is under the null that all instruments are valid.

Source: author's calculation. 
In the second robustness check, one can observe that both the sign and the significance of the results remain unchanged for alternative measures. When looking at the magnitude for variables of interest, it could be highlighted that is more important the volume of cash frozen than the length of operating cycle. Again, all the models are consistent and statistically significant.

Third and finally, we examine the non-linear relation with quantile regression models given that is likely to provide a more comprehensive picture of the effect of the working capital on the profitability. It is worth to be mentioned that the use of this model is supported by the heteroskedasticity test performed after the OLS quadratic model. Table 5 provides quantile regression results from $10 \%$ to $90 \%$ quantile.

Table 5. Robustness check-coefficient estimates from quantile regressions

\begin{tabular}{|c|c|c|c|c|c|c|c|c|c|c|}
\hline Models & (1) & (2) & (3) & (4) & (5) & (6) & (7) & (8) & (9) & (10) \\
\hline ariables & OLS & Q10 & Q20 & Q30 & Q40 & Q50 & Q60 & Q70 & Q80 & Q90 \\
\hline \multirow[t]{2}{*}{ WKCR } & $0.173^{* * *}$ & $0.269^{* * *+}$ & $0.150^{* * *}$ & $0.102^{* * *+}$ & $0.085^{* * *+}$ & $0.084^{* * *+}$ & $0.086^{* * *+}$ & $0.104^{* * *+}$ & $0.118^{* * *+}$ & $0.132^{* * *}$ \\
\hline & $(0.010)$ & $(0.027)$ & $(0.015)$ & $(0.008)$ & $(0.006)$ & $(0.007)$ & $(0.008)$ & $(0.010)$ & $(0.012)$ & $(0.017)$ \\
\hline \multirow[t]{2}{*}{$\mathrm{WKCR}^{2}$} & $-0.087^{* * *}$ & $-0.161^{* * *+}$ & $-0.091^{* * *}$ & $-0.064^{* * *+}$ & $-0.051^{* * *+}$ & $-0.044^{* * *+}$ & $-0.044^{* * *+}$ & $-0.052^{* * *+}$ & $-0.059^{* * *}$ & $-0.059^{* * *}$ \\
\hline & $(0.006)$ & $(0.016)$ & $(0.009)$ & $(0.005)$ & $(0.004)$ & $(0.004)$ & $(0.005)$ & $(0.006)$ & $(0.007)$ & $(0.010)$ \\
\hline \multirow[t]{2}{*}{ DR } & $-0.156^{* * *}$ & $-0.186^{* * *}$ & $-0.132^{* * *}$ & $-0.086^{* * *}$ & $-0.072^{* * *}$ & $-0.071^{* * *}$ & $-0.082^{* * *}$ & $-0.103^{* * *}$ & $-0.139^{* * *}$ & $-0.180^{* * *}$ \\
\hline & $(0.009)$ & $(0.024)$ & $(0.013)$ & $(0.007)$ & $(0.005)$ & $(0.006)$ & $(0.007)$ & $(0.009)$ & $(0.010)$ & $(0.015)$ \\
\hline \multirow[t]{2}{*}{ SGR } & 0.001 & -0.006 & -0.002 & -0.000 & -0.000 & 0.000 & $0.002^{*}$ & $0.008^{* * *}$ & $0.009^{* * *}$ & $0.020^{* * *}$ \\
\hline & $(0.001)$ & $(0.003)$ & $(0.002)$ & $(0.001)$ & $(0.001)$ & $(0.001)$ & $(0.001)$ & $(0.001)$ & $(0.001)$ & $(0.002)$ \\
\hline \multirow[t]{2}{*}{$\mathrm{CR}$} & $0.228^{* * *}$ & 0.048 & $0.103^{* *}$ & $0.104^{* * *}$ & $0.160^{* * *}$ & $0.218^{* * *}$ & $0.309^{* * *}$ & $0.359^{* * *}$ & $0.435^{* * *}$ & $0.513^{* * *}$ \\
\hline & $(0.021)$ & $(0.056)$ & $(0.031)$ & $(0.016)$ & $(0.013)$ & $(0.014)$ & $(0.017)$ & $(0.020)$ & $(0.024)$ & $(0.035)$ \\
\hline \multirow[t]{2}{*}{ DI08 } & $0.061^{* *}$ & $0.250^{* * *}$ & $0.107^{* *}$ & $0.057^{* * *}$ & $0.049^{* * *}$ & $0.053^{* * *}$ & $0.047^{* *}$ & 0.032 & -0.026 & $-0.133^{* * *}$ \\
\hline & $(0.022)$ & $(0.058)$ & $(0.033)$ & $(0.017)$ & $(0.013)$ & $(0.015)$ & $(0.017)$ & $(0.021)$ & $(0.025)$ & $(0.037)$ \\
\hline \multirow[t]{2}{*}{ OI05 } & $-0.038^{* * *}$ & $-0.069^{*}$ & $-0.049^{* *}$ & $-0.020^{*}$ & $-0.018^{* *}$ & $-0.018^{*}$ & $-0.026^{* *}$ & $-0.024^{*}$ & $-0.030^{*}$ & -0.018 \\
\hline & $(0.011)$ & $(0.030)$ & $(0.017)$ & $(0.009)$ & $(0.007)$ & $(0.008)$ & $(0.009)$ & $(0.011)$ & $(0.013)$ & $(0.019)$ \\
\hline \multirow[t]{2}{*}{ DCRISIS } & $0.035^{* * *}$ & $0.037^{*}$ & 0.018 & $0.012^{*}$ & $0.013^{* * *}$ & $0.022^{* * *}$ & $0.027^{* * *}$ & $0.033^{* * *}$ & $0.037^{* * *}$ & $0.026^{*}$ \\
\hline & $(0.006)$ & $(0.017)$ & $(0.009)$ & $(0.005)$ & $(0.004)$ & $(0.004)$ & $(0.005)$ & $(0.006)$ & $(0.007)$ & $(0.011)$ \\
\hline \multirow[t]{2}{*}{ CONS } & -0.007 & $-0.251^{* * *}$ & $-0.094^{* * *}$ & $-0.032^{* * *}$ & $-0.013^{*}$ & -0.003 & 0.016 & $0.048^{* * *}$ & $0.117^{* * *}$ & $0.231^{* * *}$ \\
\hline & $(0.011)$ & $(0.029)$ & $(0.016)$ & $(0.008)$ & $(0.007)$ & $(0.007)$ & $(0.009)$ & $(0.011)$ & $(0.012)$ & $(0.018)$ \\
\hline R-Squared & 0.144 & & & & & & & & & \\
\hline $\begin{array}{l}\text { Pseudo } \\
\text { R-Squared }\end{array}$ & & 0.089 & 0.067 & 0.044 & 0.040 & 0.052 & 0.071 & 0.095 & 0.125 & 0.168 \\
\hline
\end{tabular}

Notes: Standard errors in parentheses; ${ }^{*} p<0.1,{ }^{* *} p<0.05,{ }^{* * *} p<0.01 ;{ }^{+}$: Significantly different quantile regression coefficients from OLS coefficients at the $5 \%$ significance level.

Source: author's calculation. 
The expected different effects of the profitability at considered quantiles of the distribution are reflected in the size, sign, and significance of both variables of interest and controls. Regarding WKCR and its square, the sign and significance are consistent with OLS, whereas the sign indicates for WKCR that the relationship is concave upward and for its square is concave downward. This suggests that the positive effect (associated to $\mathrm{WKCR}$ ) and negative effect (associated with $\mathrm{WKCR}^{2}$ ) respectively, are more pronounced for firms at the lower and higher profitability quantiles than firms at the medium quantiles. In other words, in order to increase or at least to preserve profitability, the firms should converge to the optimal level of working capital ( 0.79 of sales).

Overall, one could be stated that the quantile coefficients are both significantly different from the zero and from OLS coefficients. The results are further supported in Figure 2, where for the working capital ratio (Fig. 2b) and its square (Fig. 2c) the quantile coefficients are outside the OLS confidence (apart $20 \%, 80 \%$ and $90 \%$ quantile).

The quantile coefficient is outside the OLS confidence interval, which reinforces the non-linear relation and stands in contrast with the simple linear relation between working capital and profitability. According to these findings, we can state that there is heterogeneity in the relationship between profitability and working capital ratio as well as other controls across different quantiles.

It's worth to be noticed that the results of all approaches are consistent with the idea of non-linear relation and optimum working capital level supported by previous studies (Baños-Caballero et al. 2012, 2014; Afrifa, Padachi 2016). The main distinction relates to the optimum level identified for our CESEE sample, considerably higher than previous samples. This lead to the statement that firms from CESEE require a longer length of cash cycle and support the motivation for the study, given different behavior in comparison with firms operating in developed economies.

Our results suggest that HGFs need to concentrate their (limited) financial, technology, and personnel resources to manage more effectively all the components of working capital (inventory, accounts receivable, and accounts payable) and thus to improve their profitability. An optimal level of working capital can be attained by "paying bills as late as possible, turning over inventories quickly, and collecting on account receivables quickly" (Enqvist et al. 2014). As highlighted by Venancio and Afrifa (2013), the availability of equipment and technology is crucial for an efficient management of working capital. For instance, by employing relevant technology, firms can have access to reports on the expiry dates of inventory or they can send easily invoices and reminders to clients. In the context of IT\&C developments, managers should review the technology employed and when feasible to adopt new solutions such like Enterprise resource planning (ERP). 
C. Boțoc, S. G. Anton. Is profitability driven by working capital management? Evidence for high-growth firms ...

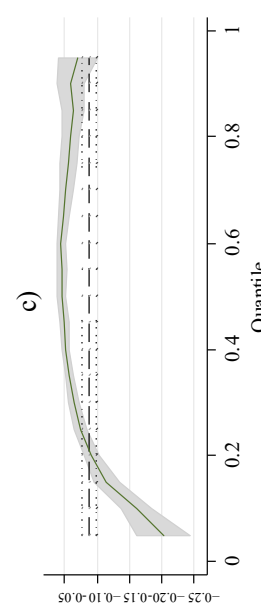

乙๖ УОУМ

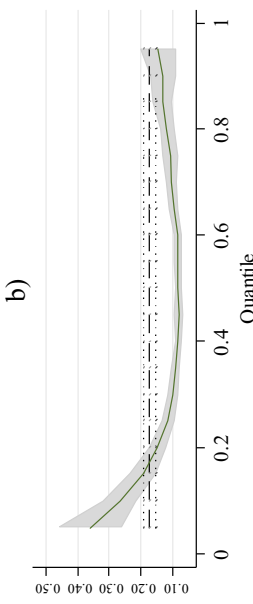

УОУМ

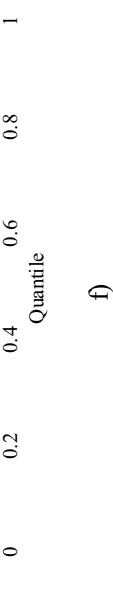

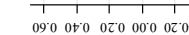

ไว
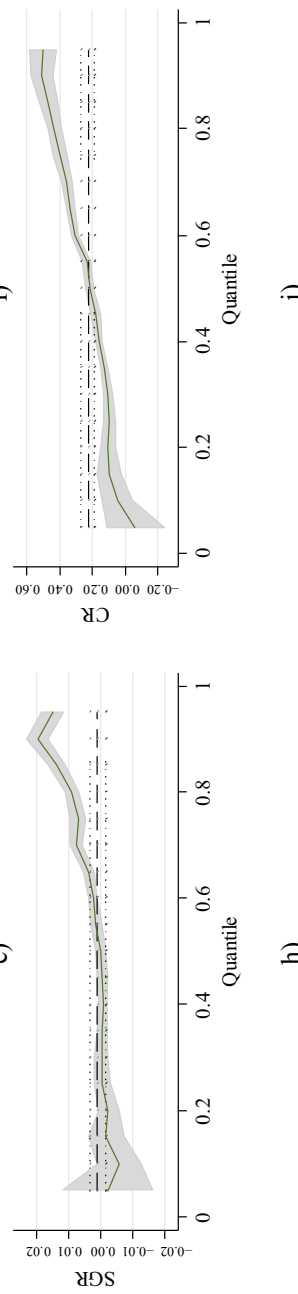

yDS

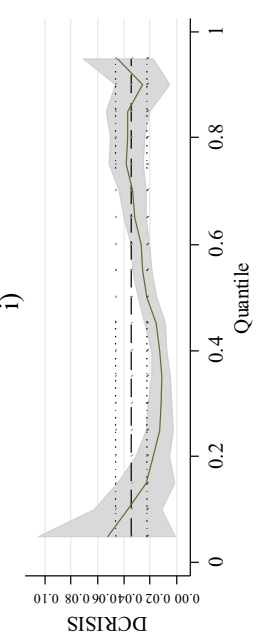

SISIYOA
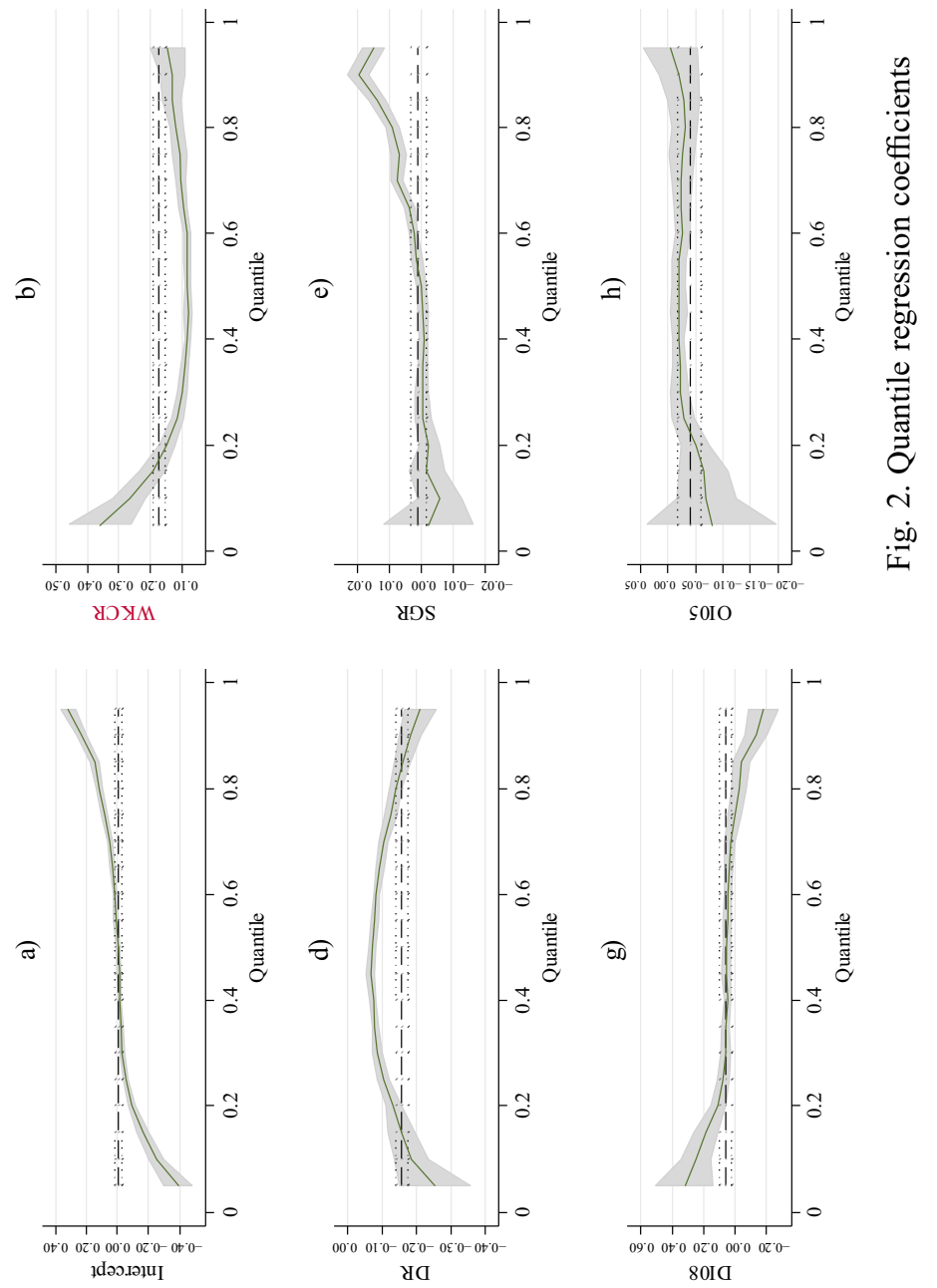

ৎOIO
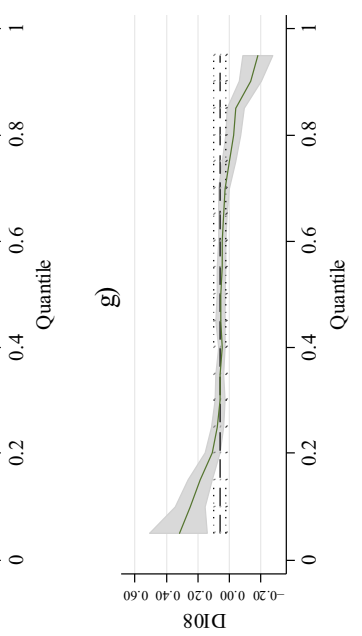


\section{Conclusions}

Despite the importance of HGFs for transition economies from CESEE region, little is known about the impact of short-term financial decisions on their profitability. Motivated by this gap in the existing literature, the aim of the paper is to assess the impact of working capital management on firm profitability in European transition countries. Using a sample of 937 high-growth firms from CESEE countries over the period 2006-2015, we found a concave (or inverted U-shape) relationship between working capital level and firm profitability. Our findings suggest that there is an optimal working capital level ( $79 \%$ of sales) at which firms' profitability is maximized. Our results proved to be robust when we employ different methodology (quantile regression), different sub-samples as well as alternative measures of profitability (return on invested capital) and working capital management (cash conversion cycle). Our findings provide empirical evidence to the need to refocus on working capital management, especially for cash-starved firms such as fast growing firms.

Given the vivid ongoing debate between theory and practice concerning the relationship between working capital and profitability, our results are relevant for both academics and practitioners. Our results partially support the modern view of working capital and could provide the motivations for future theories and research. We contribute to the extant knowledge in several ways. Firstly, it is the first paper to study the impact of short-term financial decisions on the profitability of high growth firms located in emerging markets. Hence, our paper contributes to the scarce literature on high growth firms. Secondly, contrary to previous studies, we employed new methodologies (GMM-System Model and quantile regression) and a cross country sample of firms.

It's worth to be noticed that the business model has changed from traditional one with significant level of working capital, to a different one (Twenty-First Century) based on a minimum level of $\mathrm{WC}$ and it continues to change (interconnectivity in the Twenty-First Century) based on an activity groupings that optimize the only resources that cross all organizational functions - cash and information. Therefore, the results are relevant for working capital policy and suggest that further research is required for the development of the theoretical framework.

Our findings have also significant practical implications. The level of working capital expressed as a proportion of sales is associated with the practice of an aggressive policy and therefore managers have to focus on utility maximization for the shareholders' interest. Particularly, the managers should target the optimum level and avoid an excessive increase in discounts for early payments as well as an increase in the probability of bankruptcy and credit risk.

There are three issues related to working capital that managers must deal with them in managing any business, namely risk management, efficiency, and liquidity. Downward the optimal level of 0.79 of sales they have to diagnose the business risk that firm is facing, to review the efficiency of working capital management and to meet the liquidity requirements with short-term financial resources regardless of the business environment. On the one hand, managers could determine whether Enterprise Risk 
Management (ERM) may be appropriate as a comprehensive risk management framework. On the other hand, they should focus on minimizing the level of working capital, which requires a joint effort by decision makers across all compartments. Upward the optimal level, the managers should balance the aforementioned issues in order to reach the optimal level. For instance, they could take appropriate action on receivables aging schedule, determine when to release payments and examine the efficiency of the supply chain management.

There are several limitations of our study that worth to be mentioned. Firstly, our study is focused on high-growth firms and, thus, the findings may not be generalized to all firms from emerging Europe. Secondly, as secondary data was employed, the estimations are limited in terms of available control variables regarding the firm management. Thirdly, the sample was limited by the availability of working capital ratio, which restricts the analyzed sample. Future research is thus needed in order to see whether corporate governance influences the relationship between working capital management and firm performance. Furthermore, a different sample is required in order to see if the results remain robust regardless of growth trend.

\section{References}

Acs, Z. J.; Mueller, P. 2008. Employment effects of business dynamics: mice, gazelles and elephants, Small Business Economics 30(1): 85-100. https://doi.org/10.1007/s11187-007-9052-3

Afrifa, G. A.; Padachi, K. 2016. Working capital level influence on SME profitability, Journal of Small Business and Enterprise Development 23(1): 44-63.

https://doi.org/10.1108/JSBED-01-2014-0014

Aktas, N.; Croci, E.; Petmezas, D. 2015. Is working capital management value-enhancing? Evidence from firm performance and investments, Journal of Corporate Finance 30(1): 98-113. https://doi.org/10.1016/j.jcorpfin.2014.12.008

Anyadike-Danes, M.; Bonner, K.; Hart, M.; Mason, C. 2009. Measuring business growth: high growth firms and their contribution to employment in the UK. Research Report MBG/35. National Endowment for Science, Technology and the Arts (NESTA). London [online], [cited 15 October 2016]. Available from Internet: https://www.nesta.org.uk/sites/default/files/measuring business_growth.pdf

Aregbeyen, O. 2013. The effects of working capital management on the profitability of Nigerian manufacturing firms, Journal of Business Economics and Management 14(3): 520-534.

https://dx.doi.org/10.3846/16111699.2011.651626

Arellano, M.; Bond, S. 1991. Some test of specification for panel data: Monte Carlo evidence and an application to employment equations, Review of Economic Studies 58(2): 277-297.

https://dx.doi.org/10.2307/2297968

Barjaktarović Rakočević, S.; Latinović, M.; Milosavljević, M. 2014. Working capital management practices and financial performance: evidence from Serbia, in M. L. Jakšić; S. Barjaktarović Rakočević; M. Martić (Eds.). Innovative management and firm performance. London: Palgrave Macmillan, 254-275. https://doi.org/10.1057/9781137402226

Baños-Caballero, S.; García-Teruel, P. J.; Martínez-Solano, P. 2012. How does working capital management affect the profitability of Spanish SMEs?, Small Business Economics 39(2): 517-529. https://doi.org/10.1007/s11187-011-9317-8 
Baños-Caballero, S.; García-Teruel, P. J.; Martínez-Solano, P. 2014. Working capital management, corporate performance, and financial constraints, Journal of Business Research 67(3): 332-338. https://dx.doi.org/10.1016/j.jbusres.2013.01.016

Birch, D.; Hagerty, A.; Parsons, W. 1993. Who's creating jobs?. Cambridge, MA: Cognetics.

Bolek, M. 2013. Working capital management, profitability and risk - analyse of companies listed on the Warsaw Stock Exchange, Financial Internet Quarterly ,e-Finanse” 9(3): 1-10.

Boţoc, C. 2013. The effect of working capital on profitability: evidence from Romania, Ovidius University Annals - Series Economic Sciences 13(1): 1114-1118.

Buchmann, P.; Roos, A.; Jung, U.; Wörtler, M. 2008. Cash for growth: the neglected power of working-capital management. The Boston Consulting Group [online], [cited 10 October 2016]. Available from Internet: https://www.bcgperspectives.com/

Coad, A.; Daunfeldt, S.-O.; Hölzl, W.; Johansson, D.; Nightingale, P. 2014. High-growth firms: introduction to the special section, Industrial and Corporate Change 23(1): 91-112.

https://doi.org/10.1093/icc/dtt052

Cristea, C.; Cristea, M. 2016. The impact of the working capital management on firm profitability in the Romanian manufacturing industry, Annals of the University of Oradea, Fascicle of Management and Technological Engineering 2: 107-110.

https://doi.org/10.15660/AUOFMTE.2016-2.3228

Daunfeldt, S. O.; Elert, N.; Johansson, D. 2014. The economic contribution of high-growth firms: do policy implications depend on the choice of growth indicator?, Journal of Industry, Competition and Trade 14(3): 337-365. https://doi.org/10.1007/s10842-013-0168-7

Daunfeldt, S.-O.; Johansson, D.; Halvarsson, D. 2015. Using the Eurostat-OECD definition of high-growth firms: a cautionary note, Journal of Entrepreneurship and Public Policy 4(1): 50-56. https://doi.org/10.1108/JEPP-05-2013-0020

Dănuleţiu, A. E. 2010. Working capital management and profitability: a case of Alba county companies, Annales Universitatis Apulensis Series Oeconomica 12(1): 364-374.

Deloof, M. 2003. Does working capital management affect profitability of Belgian firms?, Journal of Business Finance and Accounting 30(3/4): 573-588.

https://dx.doi.org/10.1111/1468-5957.00008

Denčić-Mihajlov, K.; Malinić, D.; Grabiński, K. 2015. Capital structure and liquidity during the financial crisis in Serbia: implications for the sustainability of the economy, Post-Communist Economies 27(1): 91-105. https://doi.org/10.1080/14631377.2015.992234

Ebben, J. J.; Johnson, A. C. 2011. Cash conversion cycle management in small firms: relationships with liquidity, invested capital, and firm performance, Journal of Small Business \& Entrepreneurship 24(3): 381-396. http://dx.doi.org/10.1080/08276331.2011.10593545

Enqvist, J.; Graham, M.; Nikkinen, J. 2014. The impact of working capital management on firm profitability in different business cycles: evidence from Finland, Research in International Business and Finance 32(August): 36-49. https://dx.doi.org/10.1016/j.ribaf.2014.03.005

Eurostat-OECD. 2007. Eurostat-OECD manual on business demography statistics [online], [cited 2 May 2016]. Available from Internet: http://www.oecd.org/std/39974460.pdf

Faden, Ch. 2014. Optimizing firm performance. Alignment of operational success drivers on the basis of empirical data. Wiesbaden: Springer.

García-Teruel, P. J.; Martínez-Solano, P. 2007. Effects of working capital management on SME profitability, International Journal of Managerial Finance 3(2): 164-177.

https://doi.org/10.1108/17439130710738718 
Giner, J. M.; Santa-Maria, M. J.; Fuster, A. 2017. High-growth firms: does location matter?, International Entrepreneurship and Management Journal 13(1): 75-96.

https://doi.org/10.1007/s11365-016-0392-9

Henrekson, M.; Johansson, D. 2010. Gazelles as job creators: a survey and interpretation of the evidence, Small Business Economics 35(2): 227-244. https://doi.org/10.1007/s11187-009-9172-z Hill, M. D.; Kelly, G.; Highfield, M. J. 2010. Net operating working capital behaviour: a first look, Financial Management 39(2): 783-805. https://dx.doi.org/10.1111/j.1755-053X.2010.01092.x

Hölzl, W. 2014. Persistence, survival, and growth: a closer look at 20 years of fast-growing firms in Austria, Industrial and Corporate Change 23(1): 199-231. https://doi.org/10.1093/icc/dtt054

Intrum Justitia. 2016. European Payment Report 2016 [online], [cited 15 February 2017]. Available from Internet: https:/www.intrum.com/globalassets/countries/norway/documents/2016/ european-payment-report-europa-2016.pdf

Koenker, R.; Bassett, G. 1978. Regression quantiles, Econometrica 46(1): 33-50.

https://doi.org/10.2307/1913643

Krasniqi, B.; Desai, S. 2016. Institutional drivers of high-growth firms: country-level evidence from 26 transition economies, Small Business Economics 47(4): 1075-1094.

https://doi.org/10.1007/s11187-016-9736-7

Lazaridis, I.; Tryfonidis, D. 2006. Relationship between working capital management and profitability of listed companies in the Athens Stock Exchange, Journal of Financial Management and Analysis 19(1): 26-35.

Lopez-Garcia, P.; Puente, S. 2012. What makes a high growth firm? A dynamic profit analysis using Spanish firm-level data, Small Business Economics 39(4): 1029-1041.

https://doi.org/10.1007/s11187-011-9321-z

Mason, C.; Brown, R. 2013. Creating good public policy to support high-growth firms, Small Business Economics 40(2): 211-225. https://doi.org/10.1007/s11187-011-9369-9

Mohr, V.; Garnsey, E.; Theyel, G. 2014. The role of alliances in the early development of highgrowth firms, Industrial and Corporate Change 23(1): 233-259.

https://doi.org/10.1093/icc/dtt056

Mun, S. G.; Jang, S. 2015. Working capital, cash holding, and profitability of restaurant firms, International Journal of Hospitality Management 48: 1-11.

https://doi.org/10.1016/j.ijhm.2015.04.003

Nightingale, P.; Coad, A. 2014. Muppets and gazelles: political and methodological biases in entrepreneurship research, Industrial and Corporate Change 23(1): 113-143.

https://doi.org/10.1093/icc/dtt057

Padachi, K. 2006. Trends in working capital management and its impact on firms' performance: an analysis of Mauritian small manufacturing firms, International Review of Business Research Papers 2(2): 45-58.

Pais, M. A.; Gama, P. M. 2015. Working capital management and SMEs profitability: Portuguese evidence, International Journal of Managerial Finance 11(3): 341-358.

https://doi.org/10.1108/IJMF-11-2014-0170

Sagner, J. 2011. Essentials of working capital management. Hoboken: John Wiley \& Sons.

Shin, H.-H.; Soenen, L. 1998. Efficiency of working capital management and corporate profitability, Financial Practice and Education 8(2): 37-45.

Stam, E.; van Stel, A. 2011. Types of entrepreneurship and economic growth, Chapter 4 in M. Goedhuys, W. Naude, E. Szirmai (Eds.). Innovation, entrepreneurship and economic development. Oxford: Oxford University Press, 78-95.

https://doi.org/10.1093/acprof:oso/9780199596515.003.0004 
Svitlík, P.; Poutník, L. 2016. Relationship between liquidity and profitability: empirical study from the Czech Republic, European Financial and Accounting Journal 11(3): 7-24. https://doi.org/10.18267/j.efaj.159

Venancio, T. V.; Afrifa, G. A. 2013. The relative importance of working capital management and its components to SMEs' profitability, Journal of Small Business and Enterprise Development 20(3): 453-469. https://doi.org/10.1108/JSBED-12-2011-0029

Windmeijer, F. 2005. A finite sample correction for the variance of linear efficient two-step GMM estimators, Journal of Econometrics 126(1): 25-51.

https://doi.org/10.1016/j.jeconom.2004.02.005

Wooldridge, J. M. 2002. Econometric analysis of cross section and panel data. Cambridge: The MIT Press.

Claudiu BOŢOC PhD is Lecturer at West University of Timişoara, Faculty of Economics and Business Administration, Finance Department. He completed a post-doctoral and doctoral programme in Finance. The main areas of research are: capital structure theories, risk - return linkage, corporate governance characteristics, financial market efficiency and volatility. His articles have been published in various international journals, such as Emerging Markets Finance and Trade, Prague Economic Papers, Journal of Economic Computation and Economic Cybernetics Studies and Research, Journal of Applied Economic Sciences, and others.

Sorin Gabriel ANTON PhD is an Associate Professor of Finance at the Faculty of Economics and Business Administration, Alexandru Ioan Cuza University of Iasi, Romania. He graduated with a Master's degree in Bank Management from the University of Rostock and took his doctorate in Finance at Alexandru Ioan Cuza University of Iasi. His research interests include international finance, risk management, and corporate finance. He has published more than 30 articles in peer-reviewed journals and 5 books. 